\title{
Coronavirus MHV-A59 infects the lung and causes severe pneumonia in C57BL/6 mice
}

\author{
Zhangsheng Yang ${ }^{1}$, Jun $\mathrm{Du}^{2}$, Gang Chen ${ }^{1}$, Jie Zhao ${ }^{1}$, Xuanming Yang ${ }^{1}$, Lishan $\mathrm{Su}^{3}$, Genhong Cheng ${ }^{4}$, \\ Hong Tang ${ }^{1 凶}$
}

1. Key Laboratory of Infection and Immunity (CASKLII), Institute of Biophysics, Chinese Academy of Sciences, 15 Datun Road, Chaoyang District, Beijing 100101, China

2. Key Laboratory of Chemical Biology and Molecular Engineering of Ministry of Education, Institute of Biotechnology, Shanxi University, Taiyuan 030006, China

3. Department of Microbiology and Immunology and Lineberger Comprehensive Cancer Center, University of North Carolina at Chapel Hill School of Medicine, NC 27599-7295, USA

4. Department of Microbiology, Immunology and Molecular Genetics, University of California, Los Angeles, CA 90095, USA

It remains challenging to develop animal models of lung infection and severe pneumonia by severe acute respiratory syndrome coronavirus (SARS-CoV) and Middle East respiratory syndrome cornavirus (MERS-CoV) without high level of containment. This inevitably hinders understanding of virushost interaction and development of appropriate countermeasures. Here we report that intranasal inoculation of sublethal doses of murine coronavirus mouse hepatitis virus A-59 (MHV-A59), a hepatic and neuronal tropic coronavirus, can induce acute pneumonia and severe lung injuries in C57BL/6 mice. Inflammatory leukocyte infiltrations, hemorrhages and fibrosis of alveolar walls can be observed 2-11 days after MHV-A59 infection. This pathological manifestation is associated with dramatical elevation of tissue IP-10 and IFN- $\gamma$ and moderate increase of TNF- $\alpha$ and IL-1 $\beta$, but inability of anti-viral type I interferon response. These results suggest that intranasal infection of MHV-A59 would serve as a surrogate mouse model of acute respiratory distress syndrome by SARS-CoV and MERS-CoV infections.

KEYWORDS coronavirus; MHV-A59; pneumonia; inflammation; cytokine

\section{INTRODUCTION}

Two novel betacoronaviruses, severe acute respiratory syndrome coronavirus (SARS-CoV) and Middle East respiratory syndrome coronavirus (MERS-CoV), have emerged in humans in this century, and both of which cause acute respiratory distress syndrome (ARDS) with high morbidity and mortality rates (Graham R L, et al., 2013). Both viruses are believed to originate in different

Received: 2 November 2014, Accepted: 10 December 2014

Published online: 22 December 2014

$\triangle$ Correspondence:

Phone: +86-27-87197727, Email: tanghong@moon.ibp.ac.cn bat species (Chan J F, et al., 2012; Ge X Y, et al., 2013; Lau S K, et al., 2005; Li W, et al., 2005; Zaki A M, et al., 2012), and have the potential to rapidly adapt and stably transmit to new species (Graham R L, et al., 2013). The patients with SARS are characterized by rapidly progressive pneumonia. The early symptoms are universal fever, myalgia, malaise and late symptoms are cough, dyspnea, tachypnea, pleurisy, and tendency of diarrhea. Most of the patients deteriorate to persistent fever, with increased dyspnea and oxygen desaturation (Peiris J S, et al., 2003). Severe histopathological alterations are evident in lung, including congestion, edema, diffuse alveolar damage, desquamation of pneumocytes, inflammatory infiltrates with hyaline membrane formation and interstitial thickening (DeAlbuquerque N, et al., 2006; Nicholls 
J M, et al., 2003). SARS patients show typical elevation of serum IFN- $\gamma$, IL-10, CXCL10/IP10, CCL5 and CXCL 8/IL-8 (Ward S E, et al., 2005).

Considering these extensive zoonotic reservoir and tendency to emerge as highly pathogenic human pathogens, it is therefore of high priority to establish valid animal models to understand virus-host interactions for drug and vaccine development. A line of animal models for SARS have been developed (Day C W, et al., 2009; De Albuquerque N, et al., 2006; DeAlbuquerque N, et al., 2006; Frieman M, et al., 2012; Leibowitz J L, et al., 2010; Ma X Z, et al., 2010; Roberts A, et al., 2007) ever since the first outbreak of SARS-CoV (Drosten C, et al., 2003; Ksiazek T G, et al., 2003; Osterhaus A D, et al., 2004; Peiris J S, et al., 2003), owing to the cross reactivity of spike protein with mouse ACE2 receptor orthologue. Closely recapitulating the clinical pathological manifestations in a progression is toward pneumonitis and diffused alveolar injury, but viremia is rare and transient. Moreover, SARS-CoV tends to adapt to mouse with elevated disease severity and mortality. MERS-CoV can transiently infect rhesus macaques with mild to moderate illness (Munster V J, et al., 2013), and common marmoset with severe pneumonia but absence of pulmorary fibrosis (Falzarano D, et al., 2014). Mice and hamsters are not permissive to MERS$\mathrm{CoV}$ due to lack of cognate receptor (Coleman C M, et al., 2014; de Wit E, et al., 2013). A humanized mouse model of MERS-CoV infection has been developed by transduction with an adenoviral vector expressing the human receptor of the virus, dipeptidyl peptidase 4 (Zhao J, et al., 2014). However, the requirements of ABSL3 level of containment and restricted license to conduct effective research further hinder the use of animal models for SARS-CoV and MERS-CoV infection.

Mouse hepatitis viruses A59 (MHV-A59) is a member of subgroup $2 \mathrm{a}$ of betacoronavirus, closely relating to human coronavirus HcoV-OC43 in the same subgroup and SARS-CoV in subgroup 2b (Graham R L, et al., 2013; Snijder E J, et al., 2003). A large body of evidence have associated pathologies with MHV-A59 infection, including hepatitis (Kim K D, et al., 2007; Weiss S R, et al., 2005; Zhao J, et al., 2008), autoimmune hepatitis-like disease (Aparicio J L, et al., 2011), thymus involution (Godfraind C, et al., 1995), hypergammaglobulinaemia (Coutelier J P, et al., 1987), and transient demyelination (Lavi E, et al., 1986). Whether MHV-A59 can infect respiratory tract and cause pathological manifestation similar to SARS-CoV infection remains elusive. Of note, MHV-A59 antigens can be detected in lung and disseminate to other tissues after neonatal Swiss mice are infected intranasally (Barthold S W, et al., 1984). Unfortunately, pathology has not been documented even in the immune compromised newborns.

To test whether MHV-A59 can infect the lungs, we intranasal inoculated C57BL/6 mice with MHV-A59. We found that MHV-A59 replicated in the lung and induced acute pneumonia, which closely mimicked ARDS by SARS-CoV and MERS-CoV in human lungs. This mouse model therefore may benefit further studies of pathogenesis of coronaviruses infection in human respiratory tracts.

\section{MATERIALS AND METHODS}

\section{Cells, Viruses and mice}

Murine cell line 17Cl-1 was provided by Dr. K. Holmes (University of Colorado Health Sciences Center, US) and immortalized wild-type MEF cells in C57BL/6 background were original from ATCC, were maintained in the medium of Dulbecco's modified Eagle medium (DMEM) supplemented with $10 \%$ heat-inactivated fetal bovine serum (FBS) and antibiotics $(100 \mu \mathrm{g} / \mathrm{mL}$ penicillin and $100 \mu \mathrm{g} / \mathrm{mL}$ streptomycin), at $37^{\circ} \mathrm{C}$ in the incubator HERAcell ${ }^{\circledR} 240$ with the presence of $5 \% \mathrm{CO}_{2}$.

Mouse hepatitis virus A59 strain (MHV-A59) was propagated according to the method described previously (Schaad M C, et al., 1990). Briefly, the virus was propagated in 17Cl-1 cells followed by 3 cycles of freezing and thawing, the large debris was spun down and the supernatant was used as a stock solution. The titer of the virus was determined by plaque assay in 17Cl-1 cells exactly as described (Schaad M C, et al., 1990).

Sendai Virus ( $\mathrm{SeV}$ ) was obtained from Wuhan Institute of Virology, Chinese Academy of Sciences, China, and expanded in day 10 SPF embryonate eggs and titrated with hemagglutination assay (HA) as described previously (Zheng D, et al., 2008). The HA tier of SeV stock was 1: 256, and for the infection of MEF cells 1: 25 was used.

C57BL/6 mice were purchased from Beijing Laboratory Animal Research Center (Beijing, China). All mice were maintained in animal facilities under specific pathogen-free conditions. The handling of mice and experimental procedures were approved by the Animal Welfare and Research Ethics Committee of the Institute of Biophysics, Chinese Academy of Sciences.

\section{Animal infection}

4 week-old C57BL/6 mice were anesthetized intraperitoneally (i.p.) with pentobarbital sodium combined with chloral hydrate, and then inoculated intranasally (i.n.) with $10 \mu \mathrm{L}$ of MHV-A59 virus at $1.5 \times 10^{5}$ or $1.5 \times 10^{4}$ plaque-forming unit (PFU), and control mice were inoculated i.n. with $10 \mu \mathrm{L}$ of $17 \mathrm{Cl}-1$ cell lysates in DMEM. The mice were monitored daily for health conditions. At intervals of 2, 5, 8, 11, and 30 days post-infection (dpi), 5 mice from each dose of infection group and 3 mice from control group were sacrificed. Lungs from infected and non-infected control mice were rinsed in ice-cold PBS, 
all tissues were separated into three portions for measurements of virus loads by plaque assays or RT-PCR, and for histological analysis (Hemmila E, et al., 2004).

\section{Viral loads by plaque assay and RT-PCR}

To quantify the infectious virus particles in the lungs, portions of the lungs removed at necropsy were weighed and homogenized in DMEM with 10\% FBS, and rapidly frozen and thawed for three times. Cell debris were removed by centrifugation, and the virus titers (PFU/g tissue) in the supernatants were determined by plaque assay on 17Cl-1 cells as described previously (Gombold J L, et al., 1993; Kim J C, et al., 1995; Lavi E, et al., 1984).

MHV-A59 $\mathrm{N}$ gene expression in the lung was analyzed by RT-PCR. Briefly, total RNA was extracted from 100 mg tissue with TRIzol reagent (Invitrogen, CA, USA), and $2 \mu \mathrm{g}$ RNA, pretreated with $1 \mathrm{U}$ of RQ1 RNase-free DNase (Fisher Scientific) to remove DNA contamination at $37{ }^{\circ} \mathrm{C}$ for $30 \mathrm{~min}$, were used for reverse transcription with oligo-dT primer (Promega). PCR reactions were then performed using the primers shown in Table 1 to detect the MHV-A59 N gene. PCR products (123 bp) were resolved by electrophoresis in $1.5 \%$ agarose gels and visualized a VersaDoc imaging system (Bio-Rad).

\section{Histopathology evaluation}

Lung tissues were removed from the mice at indicated time points, fixed in zinc formalin and processed as described previously (McCray P B, Jr., et al., 2007). For routine histology, sections were stained with hematoxylin and eosin, and the pathology of the lung was evaluated under microscope (Olympus CH30, Japan) by two independent technicians (Department of Pathology, China Agricultural University, Beijing).

\section{Cytokines profiles}

Total RNA were extracted by Trizol from tissues or MEF cells as described above and quantitative real-time RT-PCR reactions were performed using SYBR Green I (Molecular Probes, OR, USA) in a MyiQ system (BioRad, CA, USA) as described previously (Doyle S, et al., 2002). Relative levels of each gene were normalized to that of $18 \mathrm{~s}$ rRNA. Primers for different genes were listed in Table 1.

\section{Data analysis and statistical comparisons}

All data were expressed as the mean \pm standard deviations of the mean (SD). The results were analyzed statistically by using two-way ANOVA (Bonferroni post test) for body weight changes, and A Kruskal-Wallis test was used to analyze the differences in numbers of relative cytokines expression levels. Data with $p \leq 0.05(*)$ and $p \leq 0.01(* *)$ were considered statistically significant.

\section{RESULTS}

\section{Typical pneumonia was observed in MHV-A59 infection mice}

To determine whether MHV-A59 can induce lung injuries in mice, we used sub-lethal doses of the virus $\left(1.5 \times 10^{5}\right.$ or $\left.1.5 \times 10^{4} \mathrm{PFU} / \mathrm{mouse}\right)$ to intranasally (i.n.) infect 4 week-old $\mathrm{C} 57 \mathrm{BL} / 6$ mice ( $\mathrm{n}=25$ for each group). A higher dose $\left(5 \times 10^{6} \mathrm{PFU}\right.$ and above $)$ usually caused severe mortality thus not used in this study (data not shown). Mice infected by each dose began to show typical signs of illness at 3 days post-infection (dpi), including difficulty in walking, dormancy, ruffled fur and hunched posture. Infected groups lost appetite and reduced gain of body weights, as compared to the control

Table 1. Primers used for current study

\begin{tabular}{|c|c|c|}
\hline Description & Forward 5'-3' & Reverse 5'-3' \\
\hline MHV N gene & CAGATCCTTGATGATGGCGTAGT & AGAGTGTCCTATCCCGACTTTCTC \\
\hline L32 & AAGCGAAACTGGCGGAAAC & TAACCGATGTTGGGCATCAG \\
\hline 18s rRNA & CCGCGGTTCTATTTTGTTGGT & CTCTAGCGGCGCAATACGA \\
\hline IL-6 & CACAGAGGATACCACATCCCAACA & TCCACGATTTCCCAGAGAACA \\
\hline IP-10 & CCAGTGAGAATGAGGGCCATA & TCGTGGCAATGATCTCAACAC \\
\hline IFN- $\beta$ & AGCTCCAAGAAAGGACGAACAT & GCCCTGTAGGTGAGGTTGATCT \\
\hline IFN- $a 4$ & ATGGCTAGGCTCTGTGCTTCC & CATTGCAGAATGAGTCTAGGAG \\
\hline TNF- $\alpha$ & GGTGCCTATGTCTCAGCCTCTT & CGATCACCCCGAAGTTCAGTA \\
\hline IL-1 $\beta$ & CAACCAACAAGTGATATTCTCCATG & GATCCACACTCTCCAGCTGCA \\
\hline IFN-y & GCTCTGAGACAATGAACGCTAC & TTCTTCСACATCTATGCСАСTT \\
\hline IL-2 & TGAGTGCCAATTCGATGATGAG & AGGGCTTGTTGAGATGATGC \\
\hline IL-4 & САTCCTGCTCTTCTTTCTCG & ССTTCTCCTGTGACCTCGTT \\
\hline IL-5 & GGGCCTTACTTCTCCGTGTA & ACCTGAATAACATCCCAACCA \\
\hline IL-10 & GGTTGCCAAGCCTTATCGGA & АССTGCTCСАСТGССTTGCT \\
\hline IL-12p40 & GGAAGCACGGCAGCAGAATA & AACTTGAGGGAGAAGTAGGAATGG \\
\hline
\end{tabular}


mice (Figure 1A). By $6 d p i$, most of mice (25 out of 30 mice) showed apparently respiratory distress, severe loss of appetite and emaciation. The body weights of infected mice start to drop rapidly at $5 \mathrm{dpi}\left(1.5 \times 10^{5} \mathrm{PFU}\right.$ group $)$ and $6 \mathrm{dpi}$ for $\left(1.5 \times 10^{4} \mathrm{PFU}\right.$ group), respectively, which continued to decrease until to 9 to $10 \mathrm{dpi}$ (Figure 1A). One mouse in $1.5 \times 10^{5} \mathrm{PFU}$ group was deceased at 10 dpi.

More importantly, analysis of the gross pathological alteration in the lungs showed obvious pneumonia at 5 to

A

B
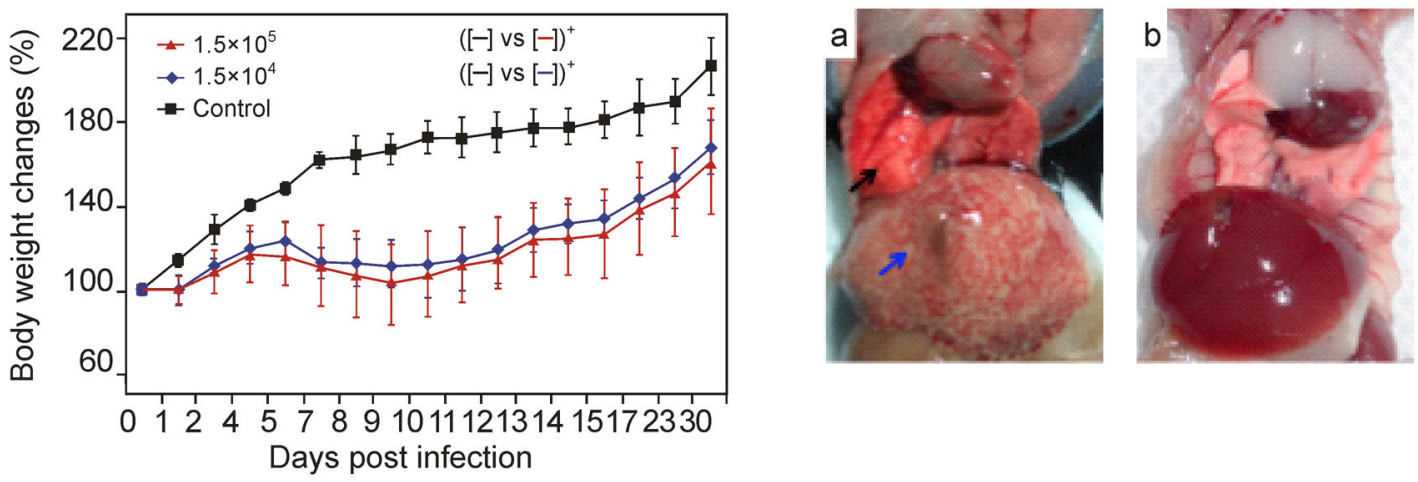

C D2 D5 D8
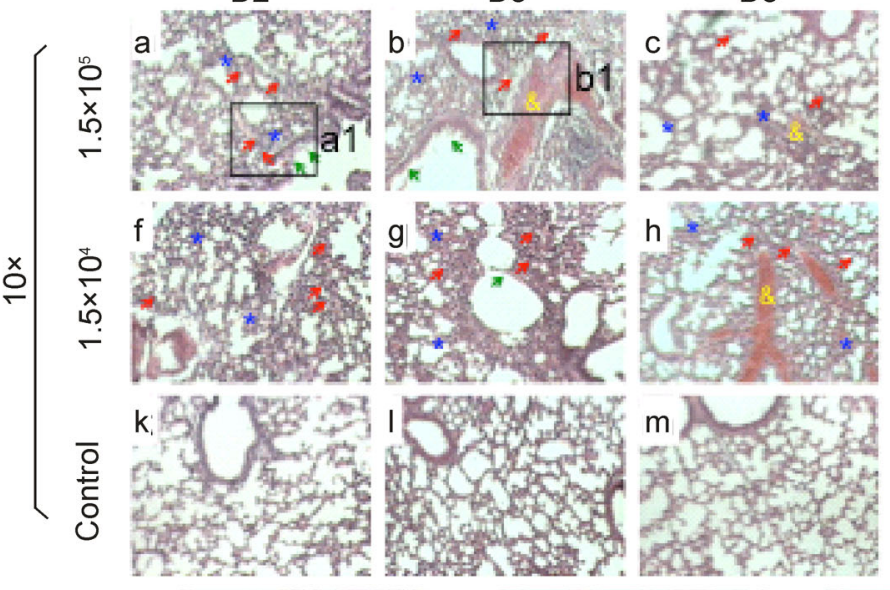

D11

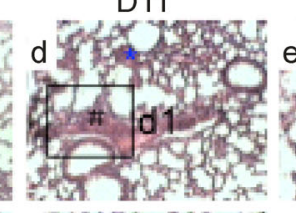

D30
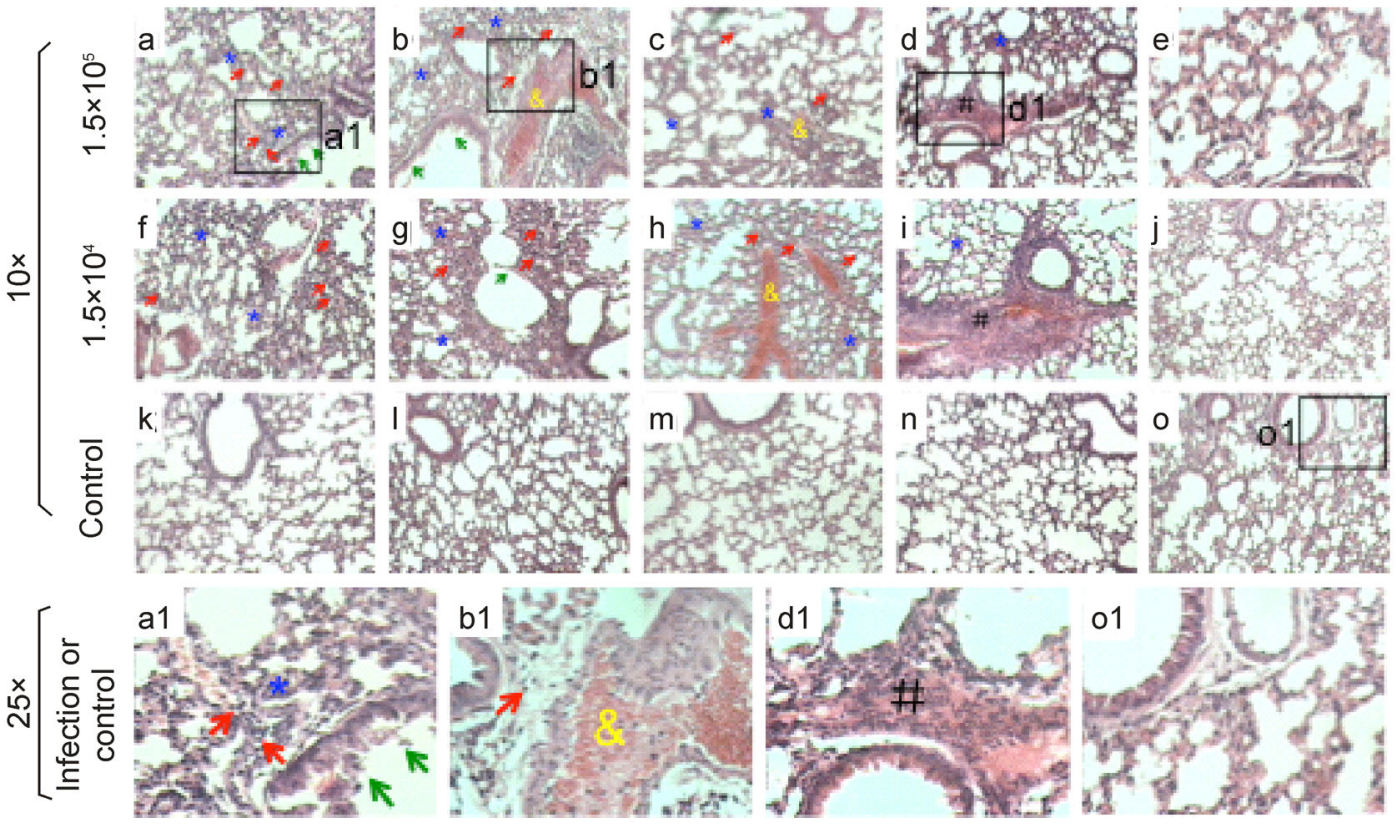

Figure 1. Pathologic alterations in C57BL/6 mice by intranasal infection of MHV-A59. A: Change of body weights were monitored daily after mice ( $n=5$ per group) were i.n. inoculated with different dose of $\mathrm{MHV}-\mathrm{A} 59$, or $17 \mathrm{Cl}$ 1 cell lysates $(n=3)$ of sham infected (see methods) as the control. Two-way ANOVA post-hoc test. ${ }^{*}, p<0.05$. $B$ : Representative of sever congestive, hemarrhagic alterations in the lung (black arrow), and obvious necrotic foci in the liver (blue arrow) of $1.5 \times 10^{5} \mathrm{PFU}$ group of mice (panel a). Control infection was shown in panel b. C: H\&E staining of the lungs of infected $(n=5)$ and control $(n=3)$ mice at indicated time post infection. Indicated was inflammatory leukocyte infiltration in the alveolar walls (red arrows), alveolar walls thickening (blue stars), mucous epithelium fell off in the bronchioles (green arrows), hemorrhages in the small blood vessels (yellow ampersands) and fibrosis in the bronchial walls and the connection tissue between alveolar (black pound). Top panels a-e were $1.5 \times 10^{5}$ PFU group, panels f-j were $1.5 \times 10^{4}$ PFU group of infection, and panels of k-o were control mice. Higher magnification $(25 x)$ images from the infection (a1, b1 and d1) or control group mouse (o1) were shown in the panels at the bottom. 
$8 \mathrm{dpi}$, and large areas of hemorrhages were evident in the lungs infected with $1.5 \times 10^{5}$ PFU MHV-A59 (Figure 1A). Both inoculation groups showed the similar progression from acute to chronic pneumonitis, with resolution at 30 $d p i$. On 2-5 dpi, both groups exhibited acute inflammatory response, including alveolar walls thickening (Figure $1 \mathrm{C}$, panels $\mathrm{a}, \mathrm{b}, \mathrm{f}, \mathrm{g}$ and $\mathrm{a} 1$, blue stars) and desquamation of mucous epithelia from the bronchioles (Figure 1C, panels $\mathrm{a}, \mathrm{b}, \mathrm{g}$ and $\mathrm{a} 1$, green arrows). Tissue damage exacerbated and peaked at 8-9 dpi, showing hemorrhages in the small blood vessels (Figure 1C, panels b, c, h and b1, yellow ampersands). The worst lung damage was correlated with the greatest loss of body weight (Figure1A). As viral infection persisted, fibrosis in the bronchial walls and the connective tissues between alveolar septa became obvious (Figure 1C, panels d, i, and d1, black pounds). At the end of experiment ( $30 \mathrm{dpi}$ ), all the mice were able to recover from pneumonic injuries, and no significantly lesions were observed. The control group of mice did not show any lesions in the lungs (Figure 1C, panels $\mathrm{k}, 1, \mathrm{~m}, \mathrm{n}, \mathrm{o}$ and $\mathrm{o} 1$ ).

Plaque assays of replicative virus in the lung homogenates showed that MHV-A59 at different inocula started to replicate in lung as early as $2 \mathrm{dpi}$ (Figure 2A, panel a), with the virus titers reaching $5 \times 10^{5}$ and $2 \times 10^{6}$ PFU per gram of tissues, respectively. Higher titer of inoculum resulted in a faster viral clearance, with $20 \%$ and $60 \%$ of mice resolved on $5 d p i$ with the high and low dose of inoculum, respectively (Figure 2A, panel b). By $8 d p i$, a very minute amount of virus could be detected in the lung ( $100 \mathrm{PFU} / \mathrm{g}$ tissue in $20 \%$ of mice), and below the detection limit by $11 d p i$ for $1.5 \times 10^{4}$ PFU group. In parallel, RT-PCR analysis of MHV-A59 $\mathrm{N}$ gene in the lung showed the similar kinetics of virus replication and clearance (Figure 2B).

Notably, as a hepatic virus, intranasal infection of MHV-A59 also caused fulminant hepatitis in C57BL/6 mice (Figure 1B), which is consistent with our previously report and others (Kim K D, et al., 2007; Lavi E, et al., 1986). Besides injuries in the lung and liver, the mice with intranasal infection of MHV-A59 also showed brain tissue damage under microscopy (data not shown), and it is consistent with the previous report (Lavi E, et al., 1986). Retention of gas in the intestines was also found in some of infected mice during necropsies (7 out of 20 mice). No obvious lesions were observed in the heart or kidney.

\section{Pro-inflammatory response to MHV-A59 infection}

Histopathological changes would associate with inflammatory leukocyte infiltration in the lung. Both MHV-A59 inoculum groups exhibited significant lymphocyte infiltration in alveolar walls (Figure 1C, panels $\mathrm{a}, \mathrm{f}, \mathrm{a} 1$ and $\mathrm{b} 1$, red arrows), which included neutrophils, macrophages and eosinophils, among others. Furthermore, quantitative RT-PCR analysis showed that type I inteferon response to MHV-A59 infection in the lung was rather limited, with transient induction of IFN- $\beta$ only at $2 d p i$, and null response of IFN- $\alpha 4$ within the course of study (Figure 3C, 3D). These results suggested that acute coronavirus infection in the lung was associated with a suppressed anti-viral type I interferon response, in agreement with our previous results in vitro (Wang G, et al., 2011; Zheng D, et al., 2008). These results further support the notion that coronaviruses may have evolved
A

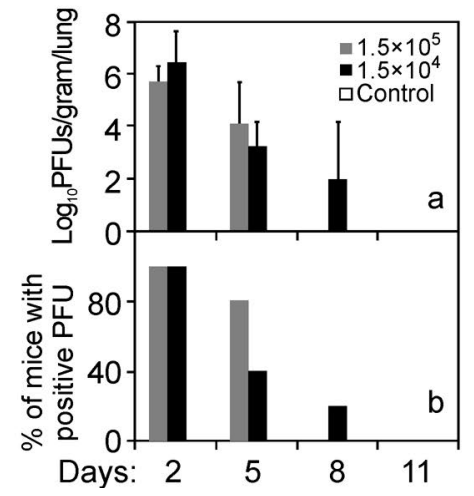

B

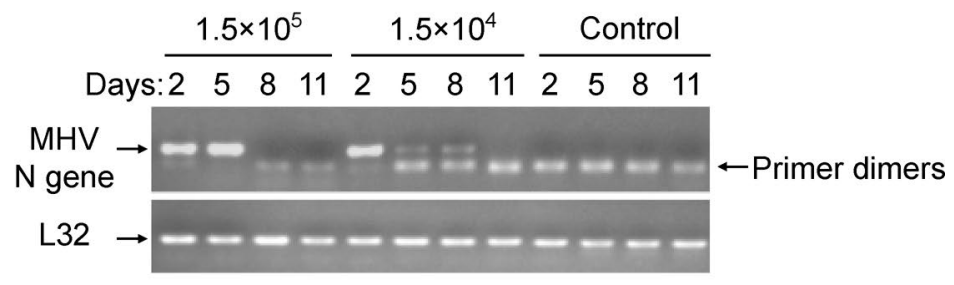

Figure 2. MHV-A59 replicated in the lung and produced infectious viral particles. A: Plaque assay measurement of production of infectious virions in the lungs $\left(\log _{10} \mathrm{PFU} / \mathrm{gram}\right.$ lung) after mice were i.n. infected with MHV-A59 $(n=5)$ or sham lysates $(n=3)$ for indicated time. The number of mice positive for detectable PFU was plotted over total number of inoculated mice (\% of positive PFU). B: Detection of MHV-A59 replication at the indicated time post inoculation. MHV-A59 $\mathrm{N}$ gene in the lung homogenates ( $\mathrm{n}=5$ for each time point post infection) from (A) was detected by standard RT-PCR amplification. L32 gene was used as a loading control. 
MHV infection
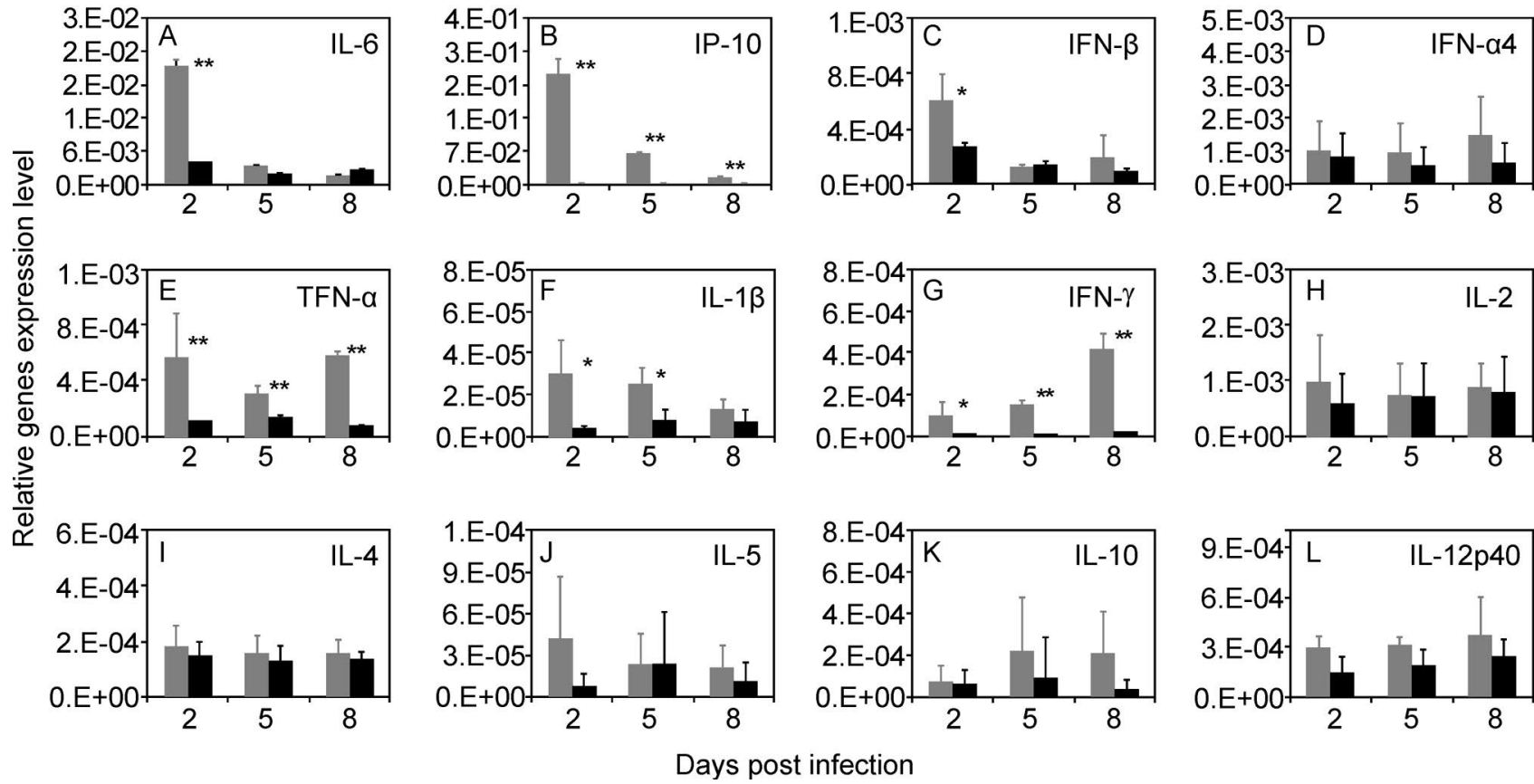

Figure 3. Proinflammatory cytokine response to MHV-A59 in the lung. Total RNA in the lung homogenates was extracted at indicated time post infection with $1.5 \times 10^{5}$ PFU MHV-A59 $(n=5)$ or sham infection $(n=3)$ as control. Real-time RT-PCR was preformed to measure indicated cytokine genes, with18s rRNA gene as internal reference. Kruskal-Wallis test. ${ }^{*} P<0.05 ;{ }^{* *}, P<0.01$.

an effective strategy to evade anti-viral innate immune response (Chen J, et al., 2007; Reghunathan R, et al., 2005; Wang G, et al., 2011; Zheng D, et al., 2008).

On the other hand, intranasal infection of MHV-A59 induced drastic up-regulation of IP-10 (Figure 3B) and IFN- $\gamma$ (Figure 3G) in the lung, especially in the early phase of infection, suggesting involvement of macrophages and NK cells in the lung injury. This result agreed with our previous finding of NK cells and IFN- $\gamma$ signal amplification in hepatopathologenesis (Kim K D, et al., 2007). The specific induction of IP-10 and suppression of IFN- $\beta$ by MHV-A59 were further confirmed in $v i$ tro. Sendai virus $(\mathrm{SeV})$ infection of murine embryonic fibroblasts (MEFs) could effectively trigger both IP-10 and IFN- $\beta$ expression (Figure $4 \mathrm{C}$ and $4 \mathrm{D}$ ). In contrast, MHV-A59 could only stimulate IP-10 but not IFN- $\beta$ expression (Figure 4A and 4B). The hyper response of IP10 and IFN $\gamma$ during MHV-A59 infection was reminiscent of that in SARS-CoV infection (Huang K J, et al., 2005; Jiang Y, et al., 2005).

Other inflammatory cytokines involved in tissue damage and repair, such as TNF- $\alpha$ and IL- $1 \beta$, were also significantly up-regulated in the lung (Figure $3 \mathrm{E}$ and $\mathrm{F}$ ). TNF- $\alpha$ is a critical cytokine for MHV-A59 induced fulminant hepatitis, as we have previously reported (Kim $\mathrm{K}$ D, et al., 2007). IL-6 levels surged at $2 d p i$ and quickly came down to the basal level then after (Fig. 3A). Typical Th1 (IL-2, IL-5 and IL-12p40) or Th2 (IL-4 and IL-10) cytokines had no significant differences between the infected and control mice (Figure 3D, 3H-3L), suggesting that $\mathrm{T}$ cells activation would not play a major role in the lung injury. The lung of neonatal mice (lack of T cells) was also susceptible to acute infection by MHV-A59, with similar morbidity and mortality compared to adult mice (data not shown), support the notion that $\mathrm{T}$ cells may be dispensable to lung injury by coronavirus infection. Therefore, these results suggested that abnormal innate inflammatory activation and amplification in the lung would attribute to tissue injury and respiratory distress during acute coronaviruses infection.

\section{DISCUSSION}

There still lacks suitable animal models to study pathogenesis of respiratory tract infection by SARS-CoV and MERS-CoV (Devitt E, 2013). This work is able to show that MHV-A59 by intranasal inoculation can lead to lung infection and severe pneumonic manifestations in C57BL/6 mice. The severity of MHV-A59 infection correlated with virus replication in the lung and causative tissue damage. Duration of lung infection reversibly correlates with the dose of inoculum, suggesting that a higher 


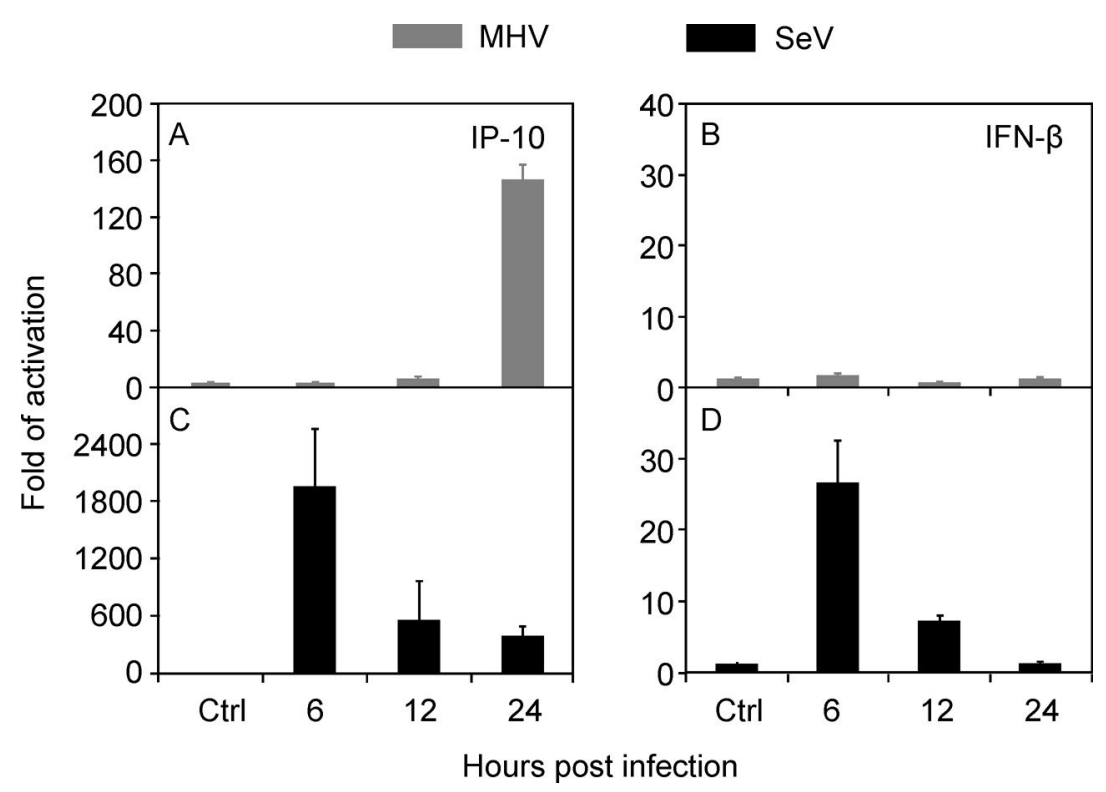

Figure 4. Differential activation of innate immune response. MEF cells $\left(1 \times 10^{6}\right)$ were infected with MHV-A59 $(\mathrm{MOI}=5)$ or SeV (HA titer at 1:25) for indicated hours. The amount of IP-10 and IFN- $\beta$ transcripts was determined by real-time RT-PCR, after normalized to $18 \mathrm{~s}$ rRNA. The data were average three independent experiments and expressed as fold of activation over that of mock infection (mean \pm SD).

dose of MHV-A59 might stimulate more robust innate immunity to control the viral infection.

Recently studies revealed that mice intranasal infection of MHV-1 resulted in acute pneumonia in the lung (De Albuquerque N, et al., 2006; DeAlbuquerque N, et al., 2006; Leibowitz J L, et al., 2010; Ma X Z, et al., 2010), which were consistent with our observations by MHV-A59 infection. Although multiple strains of mice were applied for testing of MHV-1 infection, only A/J (De Albuquerque N, et al., 2006; Leibowitz J L, et al., 2010; Ma X Z, et al., 2010) followed by $\mathrm{C} 3 \mathrm{H} / \mathrm{HeJ}$ mice (De Albuquerque N, et al., 2006) were shown of higher susceptible to the lung disease of pneumonia. However, the immunological responses maybe altered in these mice with infection of coronavirus due to the immunological components deficient. Since multiple factors including IL-3, Naip5 (Naip5 (NLR family, apoptosis inhibitory protein 5), and complement factor $\mathrm{C} 5$ were deficient in $\mathrm{A} / \mathrm{J}$ mice (JAX mice database), while $\mathrm{C} 3 \mathrm{H} / \mathrm{HeJ}$ mice was known for deficiency of TLR4 (JAX mice database).

Aberrant elevation of innate inflammatory response plays a critical role in lung injury and respiratory distress. In this sense, IP-10 may help chemoattracting NK cells (Biddison W E, et al., 1998; Farrar M A, et al., 1993; Loetscher M, et al., 1996) to lesions, as suggested in SARS (Huang K J, et al., 2005; Jiang Y, et al., 2005) and MERS patients (Chu H, et al., 2014). IFN- $\gamma$, primarily made by NK and T cells, is regarded as a pleiotropic cytokine immunomodulator that regulates a wide range of innate and adaptive immunity (Chesler D A, et al., 2002; Farrar M A, et al., 1993; Ruby J, et al., 1991). IFN- $\gamma$ is essential in development of coronaviral hepatitis (Kim K D, et al., 2007; Schijns V E, et al., 1998), MHV-JHM clearance (Marten N W, et al., 2001; Parra B, et al., 1999), and is one of major cytokine elevated in SARS patients (Huang K J, et al., 2005). MERS-CoV can also increase IFN- $\gamma$ production in infected cells (Lau S K, et al., 2013; Zhou J, et al., 2014), although little is known in MERS patients. Lastly, high mortality of ARDS patients (Meduri G U, et al., 1995; Meduri G U, et al., 1995), as well as SARS patents (He L, et al., 2006), also associates with up-regulated of IL- $1 \beta$, TNF- $\alpha$ and IL-6 in the lung. Whether and how these cytokine contribute to pulmonary epithelial damage, the leading cause of acute lung injury and ARDS, remains to be determined. Therefore, acute lung injuries induced by i.n. infection of MHV-A59 in C57BL/6 strain will benefit further investigation into the pathogenesis of human coronavirus infections in respiratory tracts.

\section{ACKNOWLEDGMENTS}

We thank Dr. Dahai Zheng for his contribution in the early phase of project development. Dr. K. Holmes (University of Colorado Health Sciences Center, US) to provide $17 \mathrm{Cl}-1$ cell line and help optimize the protocol of MHV-A59 stock preparation. We also thank Dr. Ralph Baric (University of North Carolina, US) for the 
gift of MHV-A59 and guidance of virus infection. This work was supported in part by grants from the Natural Science Foundation of China (30430640, 31030031), and the National Basic Research Program of MOST (2004BA519A61, 2003CB514116, 2006CB504300) to H.T., and Natural Science Foundation of China (31400765) to J. D.

\section{COMPLIANCE WITH ETHICS GUIDELINES}

All the authors declare that they have no conflicts of interest. This article does not contain any studies with human or animal subjects performed by the any of the authors.

\section{AUTHOR CONTRIBUTIONS}

Conceived and designed the experiments: LS, GC and HT. Performed the experiments: ZY, GC. Analyzed the data: ZY, JD, JZ, XY and HT. Wrote the paper: ZY, JD and HT.

\section{REFERENCES}

Aparicio J L, Pena C, Retegui L A. 2011. Autoimmune hepatitis-like disease in C57BL/6 mice infected with mouse hepatitis virus A59. Int Immunopharmacol, 11: 1591-1598.

Barthold S W, Smith A L. 1984. Mouse hepatitis virus strain--related patterns of tissue tropism in suckling mice. Arch Virol, 81: $103-112$

Biddison W E, Cruikshank W W, Center D M, Pelfrey C M, Taub D D, Turner R V. 1998. CD8 ${ }^{+}$myelin peptide-specific T cells can chemoattract $\mathrm{CD}^{+}$myelin peptide-specific T cells: importance of IFN-inducible protein 10. J Immunol, 160: 444-448.

Chan J F, Li K S, To K K, Cheng V C, Chen H, Yuen K Y. 2012. Is the discovery of the novel human betacoronavirus 2c EMC/2012 (HCoV-EMC) the beginning of another SARS-like pandemic? J Infect, 65: 477-489.

Chen J, Subbarao K. 2007. The Immunobiology of SARS. Annu Rev Immunol, 25: 443-472.

Chesler D A, Reiss C S. 2002. The role of IFN-gamma in immune responses to viral infections of the central nervous system. Cytokine Growth Factor Rev, 13: 441-454.

Chu H, Zhou J, Wong B H, Li C, Cheng Z S, Lin X, Poon V K, Sun T, Lau C C, Chan J F, To K K, Chan K H, Lu L, Zheng B J, Yuen K Y. 2014. Productive replication of Middle East respiratory syndrome coronavirus in monocyte-derived dendritic cells modulates innate immune response. Virology, 454-455: 197-205.

Coleman C M, Matthews K L, Goicochea L, Frieman M B. 2014. Wild-type and innate immune-deficient mice are not susceptible to the Middle East respiratory syndrome coronavirus. J Gen Virol, 95: 408-412.

Coutelier J P, van der Logt J T, Heessen F W, Warnier G, Van Snick J. 1987. IgG2a restriction of murine antibodies elicited by viral infections. J Exp Med, 165: 64-69.

Day C W, Baric R, Cai S X, Frieman M, Kumaki Y, Morrey J D, Smee D F, Barnard D L. 2009. A new mouse-adapted strain of SARS-CoV as a lethal model for evaluating antiviral agents in vitro and in vivo. Virology, 395: 210-222.
De Albuquerque N, Baig E, Ma X, Zhang J, He W, Rowe A, Habal M, Liu M, Shalev I, Downey G P, Gorczynski R, Butany J, Leibowitz J, Weiss S R, McGilvray I D, Phillips M J, Fish E N, Levy G A. 2006. Murine hepatitis virus strain 1 produces a clinically relevant model of severe acute respiratory syndrome in $\mathrm{A} /$ J mice. J Virol, 80: 10382-10394.

de Wit E, Prescott J, Baseler L, Bushmaker T, Thomas T, Lackemeyer M G, Martellaro C, Milne-Price S, Haddock E, Haagmans B L, Feldmann H, Munster V J. 2013. The Middle East respiratory syndrome coronavirus (MERS-CoV) does not replicate in Syrian hamsters. PLoS One, 8: e69127.

DeAlbuquerque N, Baig E, Xuezhong M, Shalev I, Phillips M J, Habal M, Leibowitz J, McGilvray I, Butany J, Fish E, Levy G. 2006. Murine hepatitis virus strain 1 as a model for severe acute respiratory distress syndrome (SARS). Adv Exp Med Biol, 581: 373-378.

Devitt E. 2013. Lack of small animal model hinders MERS coronavirus research. Nat Med, 19: 952.

Doyle S, Vaidya S, O'Connell R, Dadgostar H, Dempsey P, Wu T, Rao G, Sun R, Haberland M, Modlin R, Cheng G. 2002. IRF3 mediates a TLR3/TLR4-specific antiviral gene program. Immunity, 17: 251-263.

Drosten C, Gunther S, Preiser W, van der Werf S, Brodt H R, Becker S, Rabenau H, Panning M, Kolesnikova L, Fouchier R A, Berger A, Burguiere A M, Cinatl J, Eickmann M, Escriou N, Grywna K, Kramme S, Manuguerra J C, Muller S, Rickerts V, Sturmer M, Vieth S, Klenk H D, Osterhaus A D, Schmitz H, Doerr H W. 2003. Identification of a novel coronavirus in patients with severe acute respiratory syndrome. N Engl J Med, 348: 1967-1976.

Falzarano D, de Wit E, Feldmann F, Rasmussen A L, Okumura A, Peng X, Thomas M J, van Doremalen N, Haddock E, Nagy L, LaCasse R, Liu T, Zhu J, McLellan J S, Scott D P, Katze M G, Feldmann H, Munster V J. 2014. Infection with MERS-CoV causes lethal pneumonia in the common marmoset. PLoS Pathog, 10: e1004250.

Farrar M A, Schreiber R D. 1993. The molecular cell biology of interferon-gamma and its receptor. Annu Rev Immunol, 11: 571-611.

Frieman M, Yount B, Agnihothram S, Page C, Donaldson E, Roberts A, Vogel L, Woodruff B, Scorpio D, Subbarao K, Baric R S. 2012. Molecular determinants of severe acute respiratory syndrome coronavirus pathogenesis and virulence in young and aged mouse models of human disease. J Virol, 86: 884-897.

Ge X Y, Li J L, Yang X L, Chmura A A, Zhu G, Epstein J H, Mazet J K, Hu B, Zhang W, Peng C, Zhang Y J, Luo C M, Tan B, Wang N, Zhu Y, Crameri G, Zhang S Y, Wang L F, Daszak P, Shi Z L. 2013. Isolation and characterization of a bat SARS-like coronavirus that uses the ACE2 receptor. Nature, 503: 535-538.

Godfraind C, Holmes K V, Coutelier J P. 1995. Thymus involution induced by mouse hepatitis virus A59 in BALB/c mice. J Virol, 69: 6541-6547.

Gombold J L, Hingley S T, Weiss S R. 1993. Fusion-defective mutants of mouse hepatitis virus A59 contain a mutation in the spike protein cleavage signal. J Virol, 67: 4504-4512.

Graham R L, Donaldson E F, Baric R S. 2013. A decade after SARS: strategies for controlling emerging coronaviruses. Nat Rev Microbiol, 11: 836-848.

He L, Ding Y, Zhang Q, Che X, He Y, Shen H, Wang H, Li Z, Zhao L, Geng J, Deng Y, Yang L, Li J, Cai J, Qiu L, Wen K, Xu X, Jiang S. 2006. Expression of elevated levels of pro-inflammatory cytokines in SARS-CoV-infected ACE2+ cells in SARS patients: relation to the acute lung injury and pathogenesis of SARS. J Pathol, 210: 288-297.

Hemmila E, Turbide C, Olson M, Jothy S, Holmes K V, Beauche- 
min N. 2004. Ceacam 1a-/- mice are completely resistant to infection by murine coronavirus mouse hepatitis virus A59. J Virol, 78: 10156-10165.

Huang K J, Su I J, Theron M, Wu Y C, Lai S K, Liu C C, Lei H Y. 2005. An interferon-gamma-related cytokine storm in SARS patients. J Med Virol, 75: 185-194.

Jiang Y, Xu J, Zhou C, Wu Z, Zhong S, Liu J, Luo W, Chen T, Qin Q, Deng P. 2005. Characterization of cytokine/chemokine profiles of severe acute respiratory syndrome. Am J Respir Crit Care Med, 171: 850-857.

Kim J C, Spence R A, Currier P F, Lu X, Denison M R. 1995. Coronavirus protein processing and RNA synthesis is inhibited by the cysteine proteinase inhibitor E64d. Virology, 208: 1-8.

Kim K D, Zhao J, Auh S, Yang X, Du P, Tang H, Fu Y X. 2007. Adaptive immune cells temper initial innate responses. Nat Med, 13: 1248-1252.

Ksiazek T G, Erdman D, Goldsmith C S, Zaki S R, Peret T, Emery S, Tong S, Urbani C, Comer J A, Lim W, Rollin P E, Dowell S F, Ling A E, Humphrey C D, Shieh W J, Guarner J, Paddock C D, Rota P, Fields B, DeRisi J, Yang J Y, Cox N, Hughes J M, LeDuc J W, Bellini W J, Anderson L J. 2003. A novel coronavirus associated with severe acute respiratory syndrome. N Engl J Med, 348: 1953-1966.

Lau S K, Lau C C, Chan K H, Li C P, Chen H, Jin D Y, Chan J F, Woo P C, Yuen K Y. 2013. Delayed induction of proinflammatory cytokines and suppression of innate antiviral response by the novel Middle East respiratory syndrome coronavirus: implications for pathogenesis and treatment. J Gen Virol, 94: 2679-2690.

Lau S K, Woo P C, Li K S, Huang Y, Tsoi H W, Wong B H, Wong S S, Leung S Y, Chan K H, Yuen K Y. 2005. Severe acute respiratory syndrome coronavirus-like virus in Chinese horseshoe bats. Proc Natl Acad Sci U S A, 102: 14040-14045.

Lavi E, Gilden D H, Highkin M K, Weiss S R. 1986. The organ tropism of mouse hepatitis virus A59 in mice is dependent on dose and route of inoculation. Lab Anim Sci, 36: 130-135.

Lavi E, Gilden D H, Wroblewska Z, Rorke L B, Weiss S R. 1984. Experimental demyelination produced by the A59 strain of mouse hepatitis virus. Neurology, 34: 597-603.

Leibowitz J L, Srinivasa R, Williamson S T, Chua M M, Liu M, Wu S, Kang H, Ma X Z, Zhang J, Shalev I, Smith R, Phillips M J, Levy G A, Weiss S R. 2010. Genetic determinants of mouse hepatitis virus strain 1 pneumovirulence. J Virol, 84: 9278-9291.

Li W, Shi Z, Yu M, Ren W, Smith C, Epstein J H, Wang H, Crameri G, Hu Z, Zhang H, Zhang J, McEachern J, Field H, Daszak P, Eaton B T, Zhang S, Wang L F. 2005. Bats are natural reservoirs of SARS-like coronaviruses. Science, 310: 676-679.

Loetscher M, Gerber B, Loetscher P, Jones S A, Piali L, Clark-Lewis I, Baggiolini M, Moser B. 1996. Chemokine receptor specific for IP10 and mig: structure, function, and expression in activated T-lymphocytes. J Exp Med, 184: 963-969.

Ma X Z, Bartczak A, Zhang J, Khattar R, Chen L, Liu M F, Edwards A, Levy G, McGilvray I D. 2010. Proteasome inhibition in vivo promotes survival in a lethal murine model of severe acute respiratory syndrome. J Virol, 84: 12419-12428.

Marten N W, Stohlman S A, Bergmann C C. 2001. MHV infection of the CNS: mechanisms of immune-mediated control. Viral Immunol, 14: 1-18.

McCray P B Jr., Pewe L, Wohlford-Lenane C, Hickey M, Manzel L, Shi L, Netland J, Jia H P, Halabi C, Sigmund C D, Meyerholz D K, Kirby P, Look D C, Perlman S. 2007. Lethal infection of K18-hACE2 mice infected with severe acute respiratory syndrome coronavirus. J Virol, 81: 813-821.

Meduri G U, Kohler G, Headley S, Tolley E, Stentz F, Postlethwaite A. 1995. Inflammatory cytokines in the BAL of pa- tients with ARDS. Persistent elevation over time predicts poor outcome. Chest, 108: 1303-1314.

Meduri G U, Headley S, Kohler G, Stentz F, Tolley E, Umberger R, Leeper K. 1995. Persistent elevation of inflammatory cytokines predicts a poor outcome in ARDS. Plasma IL-1 beta and IL-6 levels are consistent and efficient predictors of outcome over time. Chest, 107: 1062-1073.

Munster V J, de Wit E, Feldmann H. 2013. Pneumonia from human coronavirus in a macaque model. N Engl J Med, 368: $1560-1562$.

Nicholls J M, Poon L L, Lee K C, Ng W F, Lai S T, Leung C Y, Chu C M, Hui P K, Mak K L, Lim W, Yan K W, Chan K H, Tsang N C, Guan Y, Yuen K Y, Peiris J S. 2003. Lung pathology of fatal severe acute respiratory syndrome. Lancet, 361: 17731778 .

Osterhaus A D, Fouchier R A, Kuiken T. 2004. The aetiology of SARS: Koch's postulates fulfilled. Philos Trans R Soc Lond B Biol Sci, 359: 1081-1082.

Parra B, Hinton D R, Marten N W, Bergmann C C, Lin M T, Yang C S, Stohlman S A. 1999. IFN-gamma is required for viral clearance from central nervous system oligodendroglia. J Immunol, 162: 1641-1647.

Peiris J S, Lai S T, Poon L L, Guan Y, Yam L Y, Lim W, Nicholls J, Yee W K, Yan W W, Cheung M T, Cheng V C, Chan K H, Tsang D N, Yung R W, Ng T K, Yuen K Y. 2003. Coronavirus as a possible cause of severe acute respiratory syndrome. Lancet, 361: $1319-1325$.

Reghunathan R, Jayapal M, Hsu L Y, Chng H H, Tai D, Leung B P, Melendez A J. 2005. Expression profile of immune response genes in patients with Severe Acute Respiratory Syndrome. BMC Immunol, 6: 2.

Roberts A, Deming D, Paddock C D, Cheng A, Yount B, Vogel L, Herman B D, Sheahan T, Heise M, Genrich G L, Zaki S R, Baric R, Subbarao K. 2007. A mouse-adapted SARS-coronavirus causes disease and mortality in BALB/c mice. PLoS Pathog, 3 : e5.

Ruby J, Ramshaw I. 1991. The antiviral activity of immune CD8 $\mathrm{T}$ cells is dependent on interferon-gamma. Lymphokine Cytokine Res, 10: 353-358.

Schaad M C, Stohlman S A, Egbert J, Lum K, Fu K, Wei T Jr., Baric R S. 1990. Genetics of mouse hepatitis virus transcription: identification of cistrons which may function in positive and negative strand RNA synthesis. Virology, 177: 634-645.

Schijns V E, Haagmans B L, Wierda C M, Kruithof B, Heijnen I A, Alber G, Horzinek M C. 1998. Mice lacking IL-12 develop polarized Th1 cells during viral infection. J Immunol, 160: 3958-3964.

Snijder E J, Bredenbeek P J, Dobbe J C, Thiel V, Ziebuhr J, Poon L L, Guan Y, Rozanov M, Spaan W J, Gorbalenya A E. 2003. Unique and conserved features of genome and proteome of SARS-coronavirus, an early split-off from the coronavirus group 2 lineage. J Mol Biol, 331: 991-1004.

Wang G, Chen G, Zheng D, Cheng G, Tang H. 2011. PLP2 of mouse hepatitis virus A59 (MHV-A59) targets TBK1 to negatively regulate cellular type I interferon signaling pathway. PLoS One, 6: e17192.

Ward S E, Loutfy M R, Blatt L M, Siminovitch K A, Chen J, Hinek A, Wolff B, Pham D H, Deif H, LaMere E A, Kain K C, Farcas G A, Ferguson P, Latchford M, Levy G, Fung L, Dennis J W, Lai E K, Fish E N. 2005. Dynamic changes in clinical features and cytokine/chemokine responses in SARS patients treated with interferon alfacon-1 plus corticosteroids. Antivir Ther, 10: $263-275$.

Weiss S R, Navas-Martin S. 2005. Coronavirus pathogenesis and the emerging pathogen severe acute respiratory syndrome coro- 
navirus. Microbiol Mol Biol Rev, 69: 635-664.

Zaki A M, van Boheemen S, Bestebroer T M, Osterhaus A D, Fouchier R A. 2012. Isolation of a novel coronavirus from a man with pneumonia in Saudi Arabia. N Engl J Med, 367: 1814-1820.

Zhao J, Kim K D, Yang X, Auh S, Fu Y X, Tang H. 2008. Hyper innate responses in neonates lead to increased morbidity and mortality after infection. Proc Natl Acad Sci U S A, 105: 7528-7533.

Zhao J, Li K, Wohlford-Lenane C, Agnihothram S S, Fett C, Gale M J Jr., Baric R S, Enjuanes L, Gallagher T, McCray P B Jr., Perlman S. 2014. Rapid generation of a mouse model for Mid- dle East respiratory syndrome. Proc Natl Acad Sci U S A, 111: 4970-4975.

Zheng D, Chen G, Guo B, Cheng G, Tang H. 2008. PLP2, a potent deubiquitinase from murine hepatitis virus, strongly inhibits cellular type I interferon production. Cell Res, 18: 1105-1113.

Zhou J, Chu H, Li C, Wong B H, Cheng Z S, Poon V K, Sun T, Lau C C, Wong K K, Chan J Y, Chan J F, To K K, Chan K H, Zheng B J, Yuen K Y. 2014. Active replication of Middle East respiratory syndrome coronavirus and aberrant induction of inflammatory cytokines and chemokines in human macrophages: implications for pathogenesis. J Infect Dis, 209: 1331-1342. 